\title{
Life after Refusal to Enter: Reflections of an Immigration Judge
}

\author{
Geoffrey Care
}

\section{Abstract}

This article is a personal account of an immigration judge in the UK.

The history of attitudes towards immigrants in the UK since the Edict of Nantes is briefly sketched along with the sporadic emergence of review systems of executive decisions concerning immigrants, both political and non-political, from the beginning of the twentieth century up to the current one introduced first in 1969.

The article then looks at the sort of judges recruited at first and the subject matter of most of the appeals until 1993-visitors, students, overstayers, and those seeking settlement for work, for their families to join them, and for marriage.

The article deals briefly with the development of the immigration law in this period through these sorts of cases and the issues and questions facing the judge at the time. It considers where we got our information from with its challenges and shortcomings: particularly the misunderstandings which arise in cross-cultural dialogue.

The paper deals with the differences between a tribunal system in this particular jurisdiction, which adopts an adversarial approach, and the regular courts; and with the profound impact on a judge of having to adapt to decision making in such a milieu. It also tackles how these differences affect a judge's approach, especially given the constraints imposed on his judicial independence.

It also deals with the apparent changes over the years in the attitudes of judges in the tribunal, leaving a question mark over how far they are influenced by events and public opinion.

Some of the perceived shortcomings of the tribunal system to decide immigration matters are set out in the context of what Stephen Sedley described as a "fear of public abuse or political displeasure, unwittingly favouring individuals who fit stereotypes with which I felt an affinity; affection (sympathy) or prejudice which may skew my judgment."

The demons which lurk in all systems of adjudication, asylum prominent among them, are called out by name in the judicial oath and the hope is expressed that lessons have been learned both as a judge and a person in the course of some twenty-two years in this jurisdiction.

\section{Résumé}

Cet article est le compte rendu personnel d'un juge d'immigration au Royaume Uni.

Larticle retrace les attitudes envers les immigrants au Royaume Uni depuis l'Édit de Nantes. Brièvement esquissé, l'article mentionne l'apparition sporadique de systèmes de revue de décisions exécutives concernant les immigrants, politiques et non-politiques, depuis le début du 20e siècle jusqu'au système actuel, introduit en 1969.

Larticle examine ensuite les types de juges recrutés au début et l'objet de la plupart des appels jusqu'en 1993 : visiteurs, étudiants, ceux avec un séjour prolongé sans autorisation, et ceux avec des demandes détablissement pour travailler, pour réunion familiale et pour cause de mariage.

Larticle s'adresse sommairement au développement de la loi sur l'immigration pendant cette période à la faveur de ces cas, et des questions et problèmes confrontant le juge à cette époque. Doù provenait notre information, y compris les lacunes et les défis qu'elle posait; tout particulièrement les malentendus nés de dialogues interculturels.

Larticle examine ensuite les différences qui existent entre un système axé sur le processus d'un tribunal, qui existe dans cette juridiction particulière - avec sa procédure contradictoire - et les Cours régulières, et l'impact considérable sur un juge qui doit s'habituer à prendre des décisions dans 
un tel environnement. Il touche aussi sur la façon dont ces différences influent sur l'approche d'un juge, spécialement en présence des contraintes imposées sur son indépendance.

Il aborde aussi le sujet de l'évolution apparente de lattitude des juges dans les tribunaux, et pose la question de savoir jusquà quel point ils sont influencés par les événements et lopinion publique.

Puis, l'article place quelques unes des faiblesses perçues de ce système (p. ex. le questionnement de sa capacité à pouvoir statuer sur des questions d'immigration) dans le contexte de ce qu'a dit Stephen Sedley, "la peur de l'opprobre publique ou du déplaisir politique, favorisant inconsciemment les individus qui cadrent avec les stéréotypes avec lesquels javais une affinité, de l'affection ou des préjugés qui peuvent infléchir mon jugement ».

Les démons qui sont à l'affût dans tout système décisionnel, le droit d'asile apparaissant en bonne place, sont appelés par leurs noms dans le serment judiciaire et le souhait est exprimé que des leçons ont été apprises, tant comme juge que comme simple citoyen, au cours des 22 années passées dans la juridiction.

After 5 years trial the Aliens Act [1905] stands before the bar of public opinion anathemised almost by all, understood by few. [It is] suggested that the powers of Board be transferred to [a] court of summary jurisdiction-a Stipendiary Magistrate plus 2 assessors. A Memorial from the Jewish Board of Deputies states

[inter alia] that there be an appeal to Kings Bench Division ... and better interpretation. Though Winston Churchill agreed with the former he said it would have little utility - and nothing was done. ${ }^{1}$

$\mathrm{T}$ here is no shortage of writings on immigration in general or judges in particular and as such this paper is not in competition with any of them but is simply a personal account of the experiences of one immigration judge.

Coming as I did from regular practice at the normal common law bar and bench I had had no conscious experience of immigration law. Nor had I ever given thought to the case of the migrant, whether voluntary or enforced, even though I myself migrated to Zambia where I practiced for over twenty years. $^{2}$

The issues may be familiar to most readers but perhaps some of the angles may be new. However it is not just an account of the type of issues we all had to deal with, which I see to be the most important, it is how operating amidst those issues can, hopefully, have a character-building effect on the decision maker.
I begin with a little history, by way of setting the scene for the chosen method for reviewing decisions on immigrationrelated matters by the executive.

The drive to be on the move for one reason or another, compulsory or voluntary, seems a part of man's makeup. Whether it be to find better pasture, to flee from an enemy or be taken captive, it has only become what we see as such a "problem" today with nation-states; and nation-states which are richer and nation-states which are poorer.

Generally England appears to have had no comprehensive policy of restriction on immigrants until 1905, though there had been an on-off sort of approach since the revocation of the Edict of Nantes in 1685.

At first the general feeling was one of compassion for refugees and modern asylum really began there. There was a panic reaction with the French Revolution and thereafter, with the slide into insecurity all over again in 1870, with an "Act to authorize the Removal of Aliens from the Realm," public reaction encouraged by the press has railed against "rising tides," "floods," and even "masses" of immigrants intent on harming our cosy (perhaps rosy) perception of the good life.

The rhetoric down the ages seems to portray a fear for national security, or for the integrity of one's national boundaries, although one cannot help thinking that it is much more a reluctance to share the good life; but it generates increasing restrictions which rebound on everyone, friend and foe alike. It seems there is an inbuilt potential for hostility toward an alien, arising more often than not out of ignorance-or fearignorance that all too frequently is fed by lack of informed facts and self-serving malign encouragement.

The introduction of any review whatsoever of decisions whether to admit or remove the foreigner was something of a revolution when first introduced, in a rather basic way, in 1905 to a tribunal, ${ }^{3}$ called the London Immigration Board, which generally sat in secret as a panel of three selected from a group appointed by the Home Secretary and who had magisterial, business, or administrative experience. ${ }^{4}$

The Board's comprehension of asylum was worse than dangerous. There was no further review even by the courts. ${ }^{5}$

In 1906 there were 935 people excluded and 796 appeals heard, of which 442 succeeded, and in 1910 there were 1,066 excluded and 432 appeals, of which 144 succeeded.

The Sydney Street Siege in January 1910 led to an attack on the right of refuge and Stephen Phillips wrote, "The right to asylum is being shamefully violated."

The right of review was removed by the Aliens Restriction Act $1914^{7}$ and there was no appeal against any immigration decision until a return of a system whereby the executive decision concerning the immigrant could be reviewed ${ }^{8}$ by a tribunal structure with the Immigration Appeals Act 1969. ${ }^{9}$ For better or for worse, the question what is the best-suited body 
to deal with individual claims for recognition as a refugee has been answered in this country by establishing a judicial tribunal.

This was modified in 1971 and has remained, with some changes since 2002, as the avenue for the review of almost all executive decisions of an immigration nature ever since.

It was not until 1979 when I became a part-time adjudicator-the lowest step in the judicial hierarchy for immigration appeals-that I had my first conscious encounter with immigration appeals. I say "conscious" because as a judge in Zambia I realized later that, as in India, judges can and do pay regard to the different issues which sometimes arise in the case of non-nationals.

Coming to the system without any previous experience I, along with others like myself at the time, probably with past service abroad, learned "on the job," the only training being attached for a few hearings to another adjudicator.

In the UK immigration appeals do not concern only refugees. ${ }^{10}$ Indeed until the early 1990s they hardly ever did. Not only was there no appeal as such from a decision to refuse refugee status but there were few applications and fewer refusals. The way in which an asylum issue arose before us was either on an appeal against a decision to deport the person or an in-country refusal of permission to extend a stay.

Most cases we had to deal with at the time involved visitor and student appeals, applications to set aside a deportation order, and long-term applications for settlement. Rarely, if ever, was the appellant present and yet it was his or her intentions which primarily were in issue. Only the visa or entry clearance officer in the mission abroad had the chance to see and hear the applicant and it was therefore only that view which was before us. The oral evidence was from the sponsor and, however truthful he may have been, he was not the one whose purpose in wanting to come was the question. When, as was the case at times, we allowed up to 25 per cent of the appeals, this caused much dissatisfaction in the missions and we heard all about it when we went on tour.

On one occasion my colleague hinted that he thought the adjudicator must have allowed an appeal because she was pretty and showed too much leg! There could be no other good ground for appeal, let alone success, he asserted. We all knew but no one said that adjudicator was me.

Other appeals were from refusals of an extension of permission to stay for one reason or another.

There were the "tax fraud" cases and the "Primary Purpose" appeals. The appellants in these types of case usually came from the Indian subcontinent. There were other issues which came up in appeals originating in the Caribbean or Africa.

Tax fraud arose when the sponsor, usually a man, had, on arrival, claimed either to be single and to have had no, or some particular number of, children. He would then later claim tax allowances for different family members and, when he was well settled, years later, he would apply to bring in a wife and children he could never have had if his original story had been true.

There was no data link between immigration and tax so it would not be picked up until the immigration application was made.

Years of deception did not necessarily mean he was not married or even that the children were his. They were often those of a sibling. It tested our skills at deciding credibility, often with less than adequate examination skills by representatives and-being a judicial tribunal-limited rights for the adjudicator to act as examining magistrate. As DNA was later to show, in all probability we had been getting decisions wrong as to who was and who was not related to the resident spouse.

The latter cases of Primary Purpose arose out of claims to join a new or would-be spouse. The applicant had to prove a negative: that it was not the primary purpose of the application to gain residence in the UK. Endless appeals to the courts arose and it took us years to get what we thought to be the right approach-even if the outcomes may have been questionable with tools of doubtful value. The misery caused when we were wrong hardly bears thinking about.

When the immigration appeals started in 1969 it was thought that the immigration judges needed exposure to some of the cultures and countries of the peoples whose appeals would come before them, even though many at the time had served abroad as judges, magistrates, or law officers. Thus, every two years or so, two adjudicators would be sent off for a few weeks to different regions of the world to learn what went on.

In 1988 along with Lady Elizabeth Anson we spent a month in the Middle East, Bangladesh, Thailand, and the Indian subcontinent, right up to Landikotl in the northwest frontier and the Afghani border, through what was then a place where you could buy anything from a Parker pen to a washing machine-or an AK47, probably taken from the Russians who were at that very moment departing to the north. We were fortunate to be able to see and talk to the people, more of them than had many of our colleagues before, since we had been there before and knew many people. But we still missed many of the warning signals of troubles to come.

We also, along with others, failed to take on board fully the difficulties of learning things upon which we either could not rely in hearings or would have difficulties if we did.

We all learned something of the customs of people whose countries we visited, from Sylheti in Bangladesh or Sikhs from the Punjab, but it was all too brief to assimilate any deep understanding. There was always much we did not know (and 
worse still did not realize we did not know) which made the formulation of opinions about the truth of a witness or the plausibility of a story always difficult and invariably suspect.

The extent of cross-cultural misunderstandings was not grasped and even now it taints the decisions of immigration judges on perceptions of risk in asylum appeals and the real conditions prevailing in mother countries. Unfortunately the judge tends to be suspicious of the value of the anthropologist's expert opinion which can educate him or her out of the distortion caused by their own cultural perceptions. Even the cultural relativity of telling lies is not well understood.

The use of one's own knowledge in an adversarial straightjacket has been the subject of debate for years, especially knowledge arising out of the tours abroad; but even with interpreters I have found, when seconded to assist in the backlog of appeals in South Africa, where that constraint was absent their knowledge was invaluable in deciding whether the appellant came from one side of a political boundary or the other. ${ }^{11}$

The need to have an encyclopedic knowledge of cultures and country backgrounds, and even more importantly an open mind as to how the latter can impact in individual cases and the former can give a consciousness of the inherent elusiveness of any certainty, is another major difference. This is so especially in the extent to which one may be required to be more proactive than in a normal court.

Where the adversarial type of tribunal failed miserably was to enable us to protect the reluctant (almost invariably vulnerable female) spouse who was forced to agree to marry someone she did not want to marry. We tried to persuade the Indian community in Baroda and the High Commissioner in London as long ago as 1988 to take up the matter-but nothing was done and it is still as much an issue today as it was then. ${ }^{12}$ I know of one case at least where we got it wrong and the girl was murdered.

The caseloads of asylum-and later human rights related-appeals overtook those of the non-asylum appeals increasingly from 1993. These started to hit the immigration appeals system a year or two before when just two of us dealt with the majority of appeals which had an asylum content. Recently numbers of asylum appeals as such have decreased but appeals under the European Convention on Human Rights have increased. But it was in 1993 that a separate right of appeal was created.

I was then appointed as Deputy Chief Adjudicator. I had the responsibility for organizing the disposal of asylum appeals. The logistical task was made more complex than it should have been by the inability of the Home Office to predict numbers or to be willing to release appeals in some sort of orderly fashion. Added to this was the refusal to trust the appellate authorities to organize the most efficient way of filtering unmeritorious appeals swiftly and economicallymanaging without the vast increases in resources which are now in place. ${ }^{13}$

The adversarial system applied in this jurisdiction-more than, say, in the social welfare appeals, on which tribunal I also sat for nearly ten years-grew for two reasons. Firstly the people who were appointed at the time were lawyers and familiar with an adversarial system and secondly the tribunal system, although it occupies a place of its own in the UK administrative system, is still placed in a judicial hierarchy, as it were, and decisions are reviewed by the courts. This became increasingly the case when a specific right of appeal was added from the appellate part of the immigration appeals system to the Court of Appeal.

We have seen how important such a review is, but at the same time it reinforces the judicialization of the tribunal and has limited all attempts to loosen the straightjacket.

I have said that decision making in immigration appeals is different from decision making in the ordinary course of head-to-head litigation-either civil or criminal in the regular courts-and even, but to a lesser extent, in other tribunals. ${ }^{14}$ I will deal with some of the factors which have a profound influence on decisions a judge can, or should be able to, live with.

These factors fall broadly into two groups. Matters of law fall into the first group. But it is not only the laws themselves which concern me. The first contention to be overcome was what immigration law comprises. Some judges would have excluded European Community Law as well as any other domestic law which was not designedly immigration. There was protracted debate on who has to prove what, and when and to what extent, and it had to be settled whether the same rule applied to asylum cases and any other case, and at what date the facts themselves were to be looked at. Was it to be when the original decision was made by the state or was it each time there was a hearing of the appeal?

When it came to interpretation of the law, particularly the immigration rules themselves, the tendency in earlier days was to adopt a facilitative or generous interpretation of the immigration rules, and rarely was the literal wording decisive. The rules were looked at as rules by which to decide how someone may be admitted to a country rather than how they can be kept out. The latter was the Home Office approach, sometimes with markedly different results.

Partly to do with this, and partly due to a lack of understanding of local cultures, it was to the despair of local Caribbean society, who gave voice to what they perceived to be incomprehensible unfairness in the rules in the way we decided whether a parent had had the "sole responsibility" for the upbringing of a child who had been left behind until the parent had settled in the UK and was in the position to offer 
them a home with them. In such cases the social and legal position of illegitimate children in the rules caused monstrous injustice, it was said. Even the local social workers were baffled why children should be admitted to the UK only if the parent had had sole responsibility for them: "It is as illogical as admitting the child on the size of his feet!" they said.

How the law is interpreted is especially important with human rights related appeals. We regarded the Refugee Convention as a living instrument that was set in place for the purpose of affording a substitute for the protection which the claimant's own country should have given but did not. This approach, when brought together with the extent of the "burden of proof" resting on the refugee claimant, did not admit of a literalist approach. As an example there were many cases in which it was accepted that economics could be a basis of persecution. ${ }^{15}$

Unlike today.

The extent of the family affected by removal under Article 8 of the European Convention on Human Rights has been restrictively interpreted by the Asylum and Immigration Tribunal (AIT) and it had to be the House of Lords which corrected this. ${ }^{16}$ I along with others in the UK and France had accepted that the threat of FGM (female genital mutilation) could amount to persecution but both the AIT and the Court of Appeal departed from this and again it was left to the House of Lords, in uncompromising language, to restore that approach. ${ }^{17}$

Again when it came to the exclusion from refugee status, decisions by the AIT have adopted a literalist interpretation to Article 4F of the Refugee Convention 1951 in a manner leading it to conclude that there is no room for evidence that someone who has ever committed acts which could lead to exclusion has reformed. No proof of a change of heart can prevail. ${ }^{18}$

Yet again I certainly accepted that no one who was ordered to carry out an action which amounted to crimes against humanity was obliged to carry out such an order. In that case it was as I recall carpet bombing in civilian (Kurdish) areas by the Turkish army. However the AIT has more recently held otherwise. It was put right by the Court of Appeal. ${ }^{19}$

To the second group belong everything relating to fact finding. One of the major points of difference between the regular courts, at least in serious matters of crime and some civil actions, is that the judge does not sit alone. Either there are other judges with him or her, or there is a jury, or in some cases assessors. Adjudicators and immigration judges, however, sit entirely on their own.

The judge is faced with any of one or more dilemmas: how best to make a judgment on the plausibility of a story and credibility itself; evaluating expert, documentary, and other evidence; knowing when and how to use his or her own knowledge and experience; and knowing how and when he should intervene, usually when there is no or no adequate representation.

In general terms, various authors have proposed some sort of guidelines to help with credibility, such as cultural and language filters; contamination of memory theories; vulnerability; consistency; verifiable country backgrounds; and-questionably-demeanour.

But two matters, perhaps more than anything else, have contributed to a real risk of a wrong decision, or the lack of transparency in many. The first is that most decisions by a single immigration judge turn on fact, and fact-finding is his or her weak point. It is also one on which any or any adequate training is not given. The second is the requirement that an appeal can be made based on an error of law only-and this is strictly interpreted.

Experienced judges are unanimous that picking out the liar is difficult. Whether or not it is a skill which can be learned must be open to much doubt but what is clear is that it is a quicksand to be wary of, which is a good reason for adopting the Canadian approach-if the story hangs together the appellant should not readily be branded a liar.

Relegating credibility to second place makes it less likely for a decision maker to adopt the view that an adverse credibility finding leads inevitably to the appeal being rejected. A test of "apparent reasonableness" or even common sense takes one no further since the question remains of "apparent to whom?", "common to whose sense?"

To say that credible statements must be coherent and plausible and not run counter to generally known facts 20 arguably begs the questions of how to assess plausibility and which facts are generally known facts. ${ }^{21}$

Geertz suggests it is a cultural system resting on a conviction of its validity. ${ }^{22}$ But how well qualified is that person to assess what is reasonable in the circumstances? Lee J. in the Federal Court of Canada ${ }^{23}$ asks, "how are we to separate systemic injustices from individual prejudices?"

Credibility is neither an aim itself nor some sort of points system of analysis. ${ }^{24}$ As Regina Graycar puts it, "Credibility is not itself a valid end to the function of an adjudicator." Courts all over the English-speaking world have struggled to find a formula to guide the over- or under-credulous, and to counsel caution in being too ready to reject a story. ${ }^{25}$

The approach to accepting the scenario presented has its own special problems, not the least being that it is usually presented through an interpreter. Given that there are no strict rules for guidance, the judge is thrown back on his own resources, which may be biased, often unknowingly. Or he may rely on information which has been gained by experience and absorbed as the truth, ${ }^{26}$ for example that documentary evidence from some countries is inherently unreliable, 
or the configuration of an airport in some remoter part of the world.

Again, with expert evidence one is often lacking any reliable yardstick and ends up overemphasizing the role of ultimate control over the decision-making process, falling back on civil or criminal rules and guidelines. ${ }^{27}$

For myself, adapting to the hybrid nature of an appellate system, although itself founded in an adversarial climate with adversarially trained lawyers, was a little easier having sat as a judge in a country which had no jury system and in which the quality of representation was not always good and one was nearly always working through at least one interpreter.

But for those used to this, and with the increasing supervision from superior courts, the degree of acceptable intervention and the way of introducing one's own knowledge was much less easy.

In sum, in my view, for these reasons alone a legalistic tribunal is unsuited to the sort of inquiry called for particularly in refugee appeals. Unfortunately the confrontational nature of this type of enquiry starts with the Home Office and has contributed greatly to the perception of racist and discriminatory decision making by it.

Very marked inroads into judicial independence are much more easily made to a tribunal created by statute. This has been done both by the rules and procedures themselves and by pressures brought about partly by the high profile nature of the subject matter and partly internally by production line techniques and pressures to reach a decision quickly. Bound up with the last factor of the high profile nature of immigration is the constant exposure to stories of human rights abuses which can have psychological consequences for the judge, and can lead to forms of judicial burnout-something one does not always see in oneself or those around youuntil one steps outside.

In Poland at least decisions are overseen by the Supreme Administrative Court which is not open to the sort of interference by the executive which is found constantly in the UK.

A start can be made on the attitudes and prejudices of the judge with what Lord Justice Sedley told an international conference of immigration judges:

Every one of these nouns is set in high relief by the asylum judge's functions. The fear of public abuse or political displeasure, even if neither can result in dismissal; the risk of unwittingly favouring individuals who fit stereotypes with which the judge feels an affinity; the risk that affection-sympathy—will skew judgment; the risk that ill will-prejudice-may do the same; the judicial oath calls out by name these demons which lurk in all systems of adjudication, asylum prominent among them. I do not suggest that there is any nostrum against these things, though by being aware that they exist is an important start. ${ }^{28}$
One asks, can experience and training make a “ ... good road builder"? The answer is, perhaps; but under certain conditions.

The judge must listen to the evidence, make findings of fact, and apply the law. Straightforward enough, it would seem, at least to someone brought up in the common law traditions before adversarial courts. In the immigration hearings however the issues involved and the way resolution question before the tribunal is to be resolved are different: the absence of strict rules of evidence; the opportunity to hear what the party has to say first hand; the lack of cultural understanding of many and varied appellants; not to mention the unlikelihood of having been exposed to immigration at first hand, let alone to have been a refugee, categorized as a terrorist, or tortured. Perhaps Judge Albie Sachs from South Africa is one of the very few who has experienced the lot.

There is often little to guide the judge but his experiencein another sphere. Especially in asylum appeals his duty is to reach the truth-not merely on the evidence; and yet he is not an examining magistrate and does not have the facilities to call evidence even if he knew how to do so.

If he intervenes too obviously or relies on his own knowledge he is likely to be overturned on appeal. But time and again it is obvious that investigation is incomplete at best.

Some supporting evidence, such as expert evidence, may call for its own separate evaluation before putting it into the credibility equation.

Judges regularly seem to perceive threats to their own role in expert evidence from psychiatrists and anthropologists; but do they need to?

The attitude of the judge verging on the arrogant is nowhere more apparent than when it comes to dealing with medical or country background, and especially with psychiatric evidence. His expertise is in most cases at best limited and yet he is quick to assert that the decision is his. So it isbut the attitude tends to be used to exclude any recognition that the opinion of such experts can be helpful and may be more reliable than his own. At the end of the day he just has to take responsibility whatever he does.

There is no such thing as the state having to prove the correctness of their case that he is not a refugee, beyond all reasonable doubt; it is for the would-be refugee to show it is reasonably likely that if returned he may be persecuted. But along the road the dice are loaded and no more so than that his case is before a tribunal which can be manipulated at will, from both within the system and without, if it makes too many unacceptable decisions.

I do not make decisions in court or hearing room any longer. But if I did, would I be any better at it for the experiences which I have had? We will never know. 
What has been the most profound impact on me has been to realize just how dangerous a job sitting in judgment is. Dangerous to the individual whose case I get wrong and dangerous to myself if, as Stephen Sedley said, "fear of public abuse or political displeasure, unwittingly favouring individuals who fit stereotypes with which I felt an affinity; affection (sympathy) or prejudice which may skew my judgment."

The judicial oath does indeed call out by name these demons which lurk in all systems of adjudication, asylum prominent among them. I hope it has taught me to be constantly on the lookout for where I may have gone wrong and correct the error at the first opportunity.

\section{Notes}

1. M.J. Landa, The Alien Problem and Its Remedy (London: P.S. King \& Son, 1911).

2. In those days it was Northern Rhodesia in the Federation of Rhodesia and Nyasaland, and the final court of appeal was the Federal Court of Appeal in Harare (then Salisbury), where there was a mixture of common and Roman law systems.

3. There is a long history of judicial tribunals in England, it seems [see M. Mulholland and B. Pullan, eds., Judicial Tribunals in England and Europe, 1200-1700 (Manchester University Press, 2003)]. Vaughan Bevan recites an interesting provision which no government today would welcome: that if a prosecution failed, the defendant must be paid treble his costs! See also R. v. SSHD ex parte Zamir [1980] QB 378, which showed just how far-reaching was the power to treat someone as an illegal entrant.

4. Aliens Act, 1905, c. 13.

5. See Landa, chaps. 9 and 10. Russians were returned to possible execution (Morning Leader, March 17, 1906) and in the House of Commons on March 14 "the whole work of the Home Office was being disorganized and seriously interfered with by the administration of the Act."

6. Westminster Gazette, January 12, 1911.

7. Immigration Act, 1971. The seeds of conduct conducive to the public good as a reason for removal can be found as early as the legislation in Napoleonic times.

8. Immigration Appeals Act, 1969.

9. Cmnd 4296, 1969-70.

10. In most countries there is no review still from a decision by the executive relating to any immigration decision, other than one with a human rights content.

11. See W. Kälin, "Troubled Communication: Cross Cultural Misunderstandings in the Asylum Hearing" (1986) International Migration Review 230, and the references therein, especially to Anthony Goode.

12. Despite the hopeful turn with the Forced Marriage (Civil Protection) Act 2007.

13. In the 1980s there were some sixty adjudicators throughout the UK. There are now ten times that number, but nowhere near ten times the number of appeals.
14. The Court of Appeal spoke of the unusual nature of this jurisdiction in Karanakaran and in Shah and Islam: "The civil standard of proof which treats anything which probably happened as having definitely happened, is part of a pragmatic legal fiction. It has no logical bearing on the likelihood of future events or (by parity of reasoning) the quality of past ones."

15. Baglan UKIAT 12620 1995; Obiter in Gashi and Niqshiqi [1997] INLR 97; Chiver (1997) INLR 212. Also see K. Jastram, "Economic, Social and Culture Rights as Grounds for a Claim for Refugee Status" (paper presented at the Research Workshop on Critical Issues in International Refugee Law, York University, Toronto, May 2008).

16. Until the House of Lords in Beoku-Betts v. Secretary of State for the Home Department put the AIT and the Court of Appeal right; see "Whole Family Affected by Removal of Immigrant," The Times (London) (July 8, 2008).

17. See El Kebir Conseil d'Éat (unreported).

18. [2004] UKIAT 00101 and [2005] UKIAT 00104.

19. BE(Iran) v. SSHD, The Times (London) (June 18, 2008).

20. UNHCR Handbook (1992) at 204.

21. MM[DRC] v. SSHD [2005] UKIAT19; [2005] ImmAR 198.

22. Clifford Geertz, Local Knowledge: Further Essays in Interpretive Anthropology (New York: Basic Books, 1983), 76.

23. w148/100.

24. Asif 1999 SCC; also, Regina Graycar, "The Gender of Judgments: An Introduction" in Margaret Thornton, ed., Public and Private: Feminist Legal Debates (Melbourne: Oxford University Press, 1995), 262.

25. Selliah, Federal Court of Australia, repeated in Menaa IAT.

26. Supra note 20.

27. Supra note 11. The International Association of Refugee Law Judges has at its recent conference in Cape Town agreed to propose a set of guidelines to assist judges in all jurisdictions in their approach to and reception of medically related evidence.

28. "Stemming the Tide or Keeping the Balance-The Role of the Judiciary" $\left(5^{\text {th }}\right.$ Conference, International Association of Refugee Law Judges, New Zealand, October 2002) at 325.

Richard Geoffrey Care, LL.M. (London), is the former Deputy and acting Chief Adjudicator for the Immigration Appellate Authority and a Chairman, Immigration Appeal Tribunal in the UK. Among numerous other appointments, he has served as Solicitor England and Wales; President of the Law Society of Northern Rhodesia and Law Association of Zambia; President, Patents Appeal Tribunal Zambia; and Justice of the High Court of Zambia, as well as Head of the Department of Law at the University of Jos Nigeria and part-time Lecturer with SOAS University of London. Richard Geoffrey Care is the founding President of the International Association of Refugee Law Judges. 